\title{
【論文】
}

\author{
米全量全袋検査の運用実態と課題 \\ 一放射性物質検査に関する制度的問題に着目してー \\ 小松知未.小山良太・小池（相原）晴伴 * ·伊藤亮司 ${ }^{* *}$ \\ (福島大学・*酪農学園大学・**新潟大学)
}

\section{Operational Conditions and Challenges of the Inspection Every Bag of Rice}

\author{
Tomomi KOMATSU - Ryota KOYAMA (Fukushima University) \\ Harutomo KOIKE (Rakuno Gakuen University) \\ Ryoji ITOU (Niigata University)
}

\begin{abstract}
This paper examines in detail the operational conditions of the inspection of every bag of rice in Fukushima Prefecture, identifying the status of the system and its problems. First, I determined how Fukushima's rice inspection was positioned in the broader institutional framework related to the inspection of radioactive material. Second, I summarized in detail the implementation of the inspections in Fukushima and their results. Third, I verified how the inspection results are employed. This comprehensive review identified several points with regard to the current system and how it should be revised. The main problem is that rice inspection is not stipulated in the Nuclear Emergency Response Headquarters' guidelines for monitoring and inspection, and only Fukushima Prefecture is conducting this inspection at its own discretion. Results of the rice inspections conducted in 2012 demonstrate that it was difficult within the Nuclear Emergency Response Headquarters' guidelines to provide a rapid response in cases where radiation levels exceeded standard values. It is recommended that the current system should undergo review, including a comprehensive evaluation of the Nuclear Emergency Response Headquarters, and that a framework should be established to indicate the geographical area where inspection is required. Additionally, an inspection system for rice for personal consumption or traded privately among friends and family (enkomai) should be considered; a process for these inspections does not exist within the current system.
\end{abstract}

Key words ; Rice Inspection, Inspection of Radioactive Material, Rice Distribution

\section{1. 背景と課題}

福島県は, 原子力災害から 2 年目の 2012 年 から「米全量全袋検査」を開始している。日本 学術会議〔6]は，「検査態勢の充実と農産物の
安:全性に対する消費者の信頼の再構築の事例と して, 福島県産の米の全袋検査が挙げられる」 とし，米の全袋検査を位置づけている。山川ほ か〔9〕は, 最新の検査結果を検証し, 米の全 
袋検査の意義を再確認しつつ,「現行の検査態勢 を検証して，その合理的簡易化を図りながら， 持続可能でより実行力と説得力を持つ対策への 質的転換を図ること」の重要性を述べている。

関谷・廣井〔8〕は，社会心理学上の風評被 害の特徵等をまとめた.下で, 通常通りの購買行 動に戻すためには「米の全量全袋検査」を実施 していること,「現在、ほとんどの農産物の検査 結果は検出限界值以下（N.D.）であること」と いう事実をもっと周知することが重要であると 指摘している ${ }^{11}$.

福島県農林水産部水田畑作課〔1〕では，米 全量全袋検査に関して, 2013 年 11 月〜 12月に 生産者・業者（集出荷・卸売・小売・実需）・実 施団体（地域協議会・市町村）・消費者を対象と したアンケート調査を実施している。この調查 結果から，生産・流通・消費・行政の全てにお いて米全量全袋検査に対する評価が高いこと (「評価する」79〜100\%)，この検査を実施し ていなければ取扱量がさらに減少し，価格低迷 に拍車がかかっていた可能性が高いことが示さ れた(「全量全袋検査を実施しない場合は取り扱 わない」28〜 57\%).

このデータから，福島県産米の販売不振は深 刻で『米全量全袋検査を行ったにも関わらず正 常価格で流通していない，つまり検査の効果が ない』2)というよりも，『検査を実施したこと で価格下落幅が抑えられた』という見方をすべ きであることが示唆される31.

米全量全袋検査の実施に対しては，意義を認 める提言, さらなる周知が風評被害対策として 有効であるとの研究成果, 関連主体からの高い 評価を示すアンケート結果が示され，いくつか の視点からの検証がなされている。一方で, 現 行の米全量全袋検査体制を対象とする調査研究 は少なく, 今後の展開方向に関する議論の土台 となる、米全量全袋検査の制度上の位置づけや 課題に関する体系的な整理が十分になされてい るとはいえない.

そこで本稿では，福島県における米全量全袋 検查の運用実態と検査結果を詳細に整理した上 で，制度上の位置づけとその問題点を明らかに
することを課題とする。また，制度の見直しの 方向性に関寸る考察を行う。

第一に，福帛県が米全量全袋検査を実施して いることが，放射性物質検査に関する制度の枠 組みの中でどのように位置づけられているかを 示寸。第二に，福島奨における米全量全袋検査 の実施体制（実施主体・費用負担・検查の流れ と検查点数）と検查結果を整理する。第三に， 検査結果の活用実態を確認する。最後に, これ らを棇合的に考察し，制度上の問題点と見直し の方向性を示す。

\section{2. 米全量全袋検査の法制度上の位置づけ}

\section{1 ) 米全量全袋検査に関連する制度}

厚生労働省は食品衛生法に基づき, 放射性物 質の基準值（一般食品 $100 \mathrm{~Bq} / \mathrm{kg}$, 牛乳及び乳 児用食品 $50 \mathrm{~Bq} / \mathrm{kg}$, 飲料水 $10 \mathrm{~Bq} / \mathrm{kg}$ ) を設定し, 2012 年 4 月 1 日から適用している.本稿では, 2012 年度に基隻值が設定されて以後の検査体 制について論じる。

米全量全袋検査の位置づけを確認する前に， 検査に関連する指針を 3 点挙げておく.

(A)農林水産省「24 年産稲の作付に関する方 針」（2012 年 2 月 28 日） は, 原子力災害対策 特別措置法に基づく水稲作付制限に関する指針 を示している．前年産米 $100 \mathrm{~Bq} / \mathrm{kg}$ 超が検出さ れた地域について，管理計画に基づく管理を実 施した場合に限り，作付制限の対象から除外す る方針を示している.

（B）原子力災害対策本部「検査計画，出荷制 限等の品目・区域の設定・解除の考え方」(2012 年 3 月 12 日改正）は，原子力災害対策特別措 置法に基づく出荷制限等の取扱いと検査の枠組 みを示している。ここでは，出荷・販売を目的 とした食品の検查点数の最低数が示されている. 調査点数に関する記載をみると, 過去に複数品 目で出荷制限指示の対象となった自治体では， (1)当該品目から $50 \mathrm{~Bq} / \mathrm{kg}$ を超える放射性セシウ ムが検出されれば 3 検体以上/市町村，(2)検出さ れなければ 1 検体以上/市町村を検査するよう 定めている。

(C)厚生労働省「食品中の放射性セシウムスク 
リーニング法（2012 年 3 月 1 日改正）」は，精 密分析装置（ゲルマニウム半導体検出器）の利 用だけでは検查点数が限られることから，簡易 分析装置による検查手法を定めている。

\section{2) 米全量全袋検査の3パターン}

米全量全袋検査は、これらの制度との関連に より，(1)管理計画による検査（(A)の枠組み）, (2) モニタリング検査計画によるスクリーニング 検査 ((B)の枠組み)，(3)自主検査に区分される. (1)(2)はどちらも(C)「食品中の放射性セシウムス クリーニング法」に準拠した検査である。

(1)管理計画による米全量全袋検查は，(A)「24 年産稲の作付に関する方針」により作付制限・ 出荷制限等の指示を受けた区域における検査で ある. 出荷販売する米だけでなく, 飯米・粶故 米を含めた全量全袋が対象となる. 2012 年度は 福島県の一部 4 ), 2013 年度は福島県・宮城県の 一部5)で実施されている. 都道府県・市町村が 厳重な管理を行える体制を整備した場合のみ, 水稲作付けが認められる.

(2) モニタリング検査計画によるスクリーニン グ検查としての米全量全袋検査は，（B）「検査 計画, 出荷制限等の品目・区域の設定・解除の 考え方」に沿った「地方自治体における検査計 画」に基づく検査である.

モニタリング検査では，市町村あたり $1 〜 3$ 点のサンプル検查を行うことが定められている が，このサンプル数を最低数と捉え，検査体制 を強化するために, 都道府県の判断で米全量全 袋検査を加えた計画を策定することが可能であ る. 福島県のみが, 米全量全袋検査の実施をモ ニタリング検査計画に加えている.

(3)自主検査としての米全量全袋検査は、「地方 自治体における検查計画」によるモニタリング 検査の範囲外で, 生産者団体・集出荷業者・小 売業者が農林水産物の安全・茹心を確保するた めに実施する検查である。

\section{3）福島県の米全量全袋検査の枠組み}

福島県の米全量全袋検査について, 実施エリ アと実施対象を確認する。

福島県では, 県内全域を米全量全袋検査の実 施エリアとしている。(1)管理計画による検査を
行う地域以外の全てを(2)モニタリング検査計画 によるスクリーニング検査の対象とすることで, 『全域』全量全袋検査を実施している。

福島県内の放射性物質污染レベルは，環境省 の除染対策事業の枠組みから 3 段階に分けられ る. 12 市町村は国直轄で除染事業を行う「除染 特別地域」(避難地域)，40市町村は市町村が事 業主体となる「污染状況重点調査地域」, 10 市 町村は対象外地域（会津地方の一部）に区分さ れている。米全量全袋検査は, 除染事業の対象 となっていないエリアも含め, 福島県の全域で 実施している。

除染事業の対象となる「污染状況重点調査地 域」は, 福島県だけではなく岩手県・宮城県・ 茨城県・栃木県・群馬県・埼玉県 $\cdot 千$ 葉県の計 8 県に点在しているものの, 放射性物質対策の エリア区分とは関倸なく，県境をラインに米の 検査体制が大きく異なっているといえる.

実施対象を確認すると, 福島県では, 飯米・ 粶故米も含めた『全量』を検査対象としている. モニタリング検查は, 出荷・販売目的の検查が 原則だが, 福島県では, 飯米・縁故米も含めた

『全量』を対象に全袋検査を行っている.

\section{3、福島県における米全量全袋検查の運用実態} 1) 実施主体

福島県においては, 2012 年 5 月に「ふくしま の恵み安全対策協議会」が設立されている。協 議会の事業内容は，(1)各地域における放射性物 質検査の推進 (米・野菜・果実ほか)，(2)検査結 果等の情報提供及び可視化対策, (3)地域協議会 等との連絡調整, (4)その他である.

表 1 に県段階の協議会構成員を示した。福島 県農林水産部, 福島県農業振興公社, 農協, 米 · 青果物の流通販売関連団体などが構成員となっ ている.この県段階協議会の下に，37 の地域段 階協議会が組織されている.

管理計画による米全量全袋検査は県・市町村 が，モニタリング検査計画による米全量全袋検 査は「ふくしまの恵み安全対策協議会」が推進 主体となっている。 
表 1 ふくしまの惠み安全対策協議会

\begin{tabular}{|c|c|c|}
\hline 役職 & 団体名 & 区分 \\
\hline & 福島県農林水産部 & 行政 \\
\hline 会長 & (財)福島県農業振興公社 & \\
\hline 副会長 & $\mathrm{JA}$ 福島中央会 & \multirow{2}{*}{$\begin{array}{c}\mathrm{JA} \\
\text { グルーブ }\end{array}$} \\
\hline & 全農福島県本部 & \\
\hline 副会長 & 福島県米穀肥料協同組合 & \multirow{3}{*}{ 米流通 } \\
\hline & 福島県米麦事業協同組合 & \\
\hline & 福島第一食料卸協同組合 & \\
\hline & 福島県青果市場連合会 & 青果物 \\
\hline & $\begin{array}{l}\text { JA伊達みらい } \\
\text { 「みらい百彩館んめーべ」 }\end{array}$ & 直売所 \\
\hline & (株)いちい & 小売店 \\
\hline & 福島県農業共済組合連合会 & \multirow{2}{*}{$\begin{array}{c}\text { データ } \\
\text { 提供協力 }\end{array}$} \\
\hline 監事 & 福島県農業会議 & \\
\hline 監事 & 福島県消費者団体連絡協議会 & \\
\hline
\end{tabular}

資料：「ふくしまの恵み安全対策協議会規約」（2012 年 5 月).

\section{2 ) 費用負担}

福島県における米全量全袋検査に関わる費用 は, 検查機器購入に約 40 億円（ベルトコンベ ア式検查器約 2,000 万円/台 $\times 193$ 台)，検査実施 に 50 億円/年（調査点数で割ると 500 円 $/ 30 \mathrm{~kg}$ 紙袋）となっている。費用は，県予算と東京電 力に対する損害賠償により支払われている。

福島県予算では,「ふくしまの恵み安全・安心 推進事業」（2012 年度 50 億円，2013 年度 9 億 円，2014 年度 7 億円）として初期費用（検查機 器・協議会設置・データシステム構筑）を計上 している6).

初期費用以外は,「ふくしまの恵み安全対策協 議会」が東京電力に対する損害賠償請求を行っ ている ${ }^{7)}$. 原子力損害賠償紛争審查会指針では，

「検查費用のうち政府が本件事故に関し検査の 指示等を行った」場合の検査費用は賠償すべき であると定められている。法制度上の位置づけ が，損害賠償の対象になるかどうかの判断基準 になっており，自主検査として実施した場合は， 費用は自己負担になる可能性が高い。

協議会は, 飯米・縁故米用も含めた『全量』 の検查費用を請求している。検查費用として, 人件費 (専任臨時職員), 機械施設維持費, 光熱 動力費，運搬費，消耗品費等を請求し， 2012 年度, 2013 年度分は支払いが決定している。

3) 検査の流れと検査点数
福島県水田畑作課「米の全量全袋検査の手引 き」(2012 年 8 月) は, 管理計画による検査と, モニタリング検査計画によるスクリーニング検 査のマニュアルを記している．表 2 は、この手 引きをもとに全量全袋検査と管理システムの概 要をまとめた表である。どちらの検査も『全量』 を対象としており販売用・飯米・縁故米の全て を検査している．検查は(C)「食品中の放射性セ シウムスクリーニング法」に準拠して実施する ため, 測定機器・手法に違いはない. $30 \mathrm{~kg}$ 紙袋 は全てベルトコンベア式検査器により検査して おり，米袋識別コードラベル発行・測定データ の公表は，共通仕様を用いている。

主な相違点は，(1)管理計画による検査は，行 政による生産・出荷管理と一体化しているが, (2)モニタリング検査計画によるスクリーニング 検査では，生産管理は生産者自身が可能な範囲 で区分管理することとされている点である。

表 2 福島県における全量全袋検査と管理システム

\begin{tabular}{|c|c|}
\hline $\begin{array}{c}\text { (1) 管理計画 } \\
\text { 福島県・市町村 } \\
\text { 対象：出荷・販売用 } \\
\text { - 飯米・粶故米 }\end{array}$ & 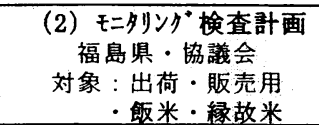 \\
\hline 市町村名・生産者名 & 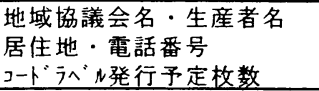 \\
\hline \multicolumn{2}{|c|}{ 米袋識別コードラベル発行 } \\
\hline $\begin{array}{l}\text { ほ場の地番 } \\
\text { 作付面積・作付品種 } \\
\text { 放射性物質吸収抑制 } \\
\text { 対策確認票 } \\
\text { 現地確認（7月末まで） } \\
\text { 管理日誌 } \\
\text { (収稪時期・収惒予定数量 } \\
\text { 保管場所・出荷予定時期) } \\
\text { 異物混入・付着防止 } \\
\text { 対策確認票 }\end{array}$ & 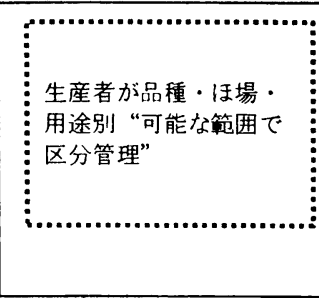 \\
\hline \multicolumn{2}{|c|}{ 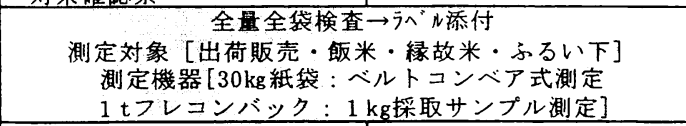 } \\
\hline 出荷時の紙袋・フレコン & 大型乾燥施設 5 点/貯留瓶 \\
\hline 予測収穫量と整合性確認 & \\
\hline & \\
\hline
\end{tabular}

資料: 福島県水田畑作課「米の全量全袋検査の手引き」 （2012 年 8 月）をもとに筆者作成.

表 3 に,福島県における米調查点数を示した。 検査点数は，各年次とも約 1,000 万袋である.

管理計画による検査は， 2012 年 122 万点 $(11 \%), 2013$ 年 53 万点 $(5 \%)$ である. 全量 
全袋検査により管理することを前提に，作付制 限から除外され，生産が可能となった米が県生 産量の 5〜11\%存在していることが分かる。管 理計画による検査において基準值を超える玄米 が確認された場合は，当該検体のみが隔離・廃 萧される。

2012 年産は, モニタリング検査結果により $100 \mathrm{~Bq} / \mathrm{kg}$ を超える検体が検出され, 出荷制限 が指示された後，急遽，管理計画に基づく管理 を行い出荷制限が解除された区域が 7 地区 $(27$ 万袋）存在している.

モニタリング検査計画によるスクリーニング 検査では, 2012 年産のみベルトコンベア式検査 器によるサンプル抽出検査を実施したが，2013 年産からは全量全袋検査に一本化されている。

\section{表 3 福島県における米調査点数}

\begin{tabular}{|c|c|c|c|}
\hline & & $\begin{array}{c}2012 \text { 年産 } \\
\text { 点数 }\end{array}$ & $\begin{array}{c}2013 \text { 年産 } \\
\text { 点数 }\end{array}$ \\
\hline \multirow{3}{*}{$\begin{array}{l}\text { 全量 } \\
\text { 全袋 }\end{array}$} & $\begin{array}{l}\text { 全量生産 } \\
\text { 出荷管理 }\end{array}$ & 950,092 & 534,633 \\
\hline & $\begin{array}{l}\text { 作付再開 } \\
\text { 淮備区域 }\end{array}$ & 区分なし & 21,900 \\
\hline & $\begin{array}{l}\text { 出荷制限 } \\
\rightarrow \text { 解除 }\end{array}$ & 272,220 & 該当なし \\
\hline \multirow{3}{*}{ 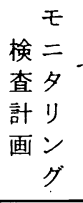 } & 全量全袋 & $9,088,315$ & $10,443,310$ \\
\hline & 早期出荷米 & 6,990 & \multirow{3}{*}{ 該当なし } \\
\hline & 一般米 & 22,948 & \\
\hline $\begin{array}{l}\text { サンプル } \\
\text { 抽出 }\end{array}$ & $\begin{array}{l}\text { 前年 } \\
50 \mathrm{Bg} / \mathrm{kg} \text { 超 }\end{array}$ & & \\
\hline \multicolumn{2}{|c|}{$\begin{array}{c}\text { スクリーニング } \\
\text { ，詳細検査 }\end{array}$} & 867 & 692 \\
\hline \multicolumn{2}{|c|}{ 検査点数 合計 } & $10,346,058$ & $11,000,535$ \\
\hline
\end{tabular}

資料：「ふくしまの恵み安全対策協議会」ウェブページ (2014 年 8 月), 福島県水田畑作課調査結果をも とに筆者作成。

\section{4 ）検査結果の公開}

全量全袋検査の結果は「ふくしまの恵み安全 対策協議会」ウェブページで公開されている。 結果は $25 \mathrm{~Bq} / \mathrm{kg}$ 区分で集計された実数・割合・ 棒グラフの形式で公表されており，調査期間・ 市町村を指定して表示できる仕様になっている。

表 4 に米全量全袋検査の結果を示した。全量 全袋検査の結果スクリーニングレベルを超えた
検体と協議会が必要と判断した検体が詳細検査 の対象となる。ゲルマニウム半導体検出器によ る詳細検査が行われた検体㳉, 2012 年 867 点, 2013 年 692 点である。その結果，基準值 $100 \mathrm{~Bq} / \mathrm{kg}$ を超えていた調査点数は，2012 年 71 点 $(0.0007 \%), 2013$ 年 28 点 $(0.0003 \%)$ で あった ${ }^{8)}$. 基準值を超える玄米の割合は，検出 率の高い市町村でも $0.013 \%$ となっており（福 島市, 一部管理計画対象区域), サンプリング調 查での基準值超過の摂取・流通防止は極めて困 難であることが分かる。一部の地域においては， 米全量全袋検査を行わなければ，基準值超流通 の可能性が拭えない状況が続いていたといえる

表 4 福島県における米全量全袋検査の結果

\begin{tabular}{|c|c|c|c|c|c|}
\hline & $\begin{array}{l}\text { 検出下限値 } \\
\text { 未満 }(<25)\end{array}$ & $\begin{array}{l}25-50 \\
\mathrm{~Bq} / \mathrm{kg}\end{array}$ & $\begin{array}{l}51-75 \\
\mathrm{~Bq} / \mathrm{kg}\end{array}$ & $\begin{array}{l}76-100 \\
\mathrm{~Bq} / \mathrm{kg}\end{array}$ & $\begin{array}{l}100 \\
\mathrm{~Bq} / \mathrm{kg} \\
\text { 超 }\end{array}$ \\
\hline 2012年産 & $10,323,419$ & 20,317 & 1,383 & 72 & \\
\hline 詳細 & 144 & 40 & 295 & 317 & 71 \\
\hline 2013 年産 & $10,993,140$ & 6,478 & 224 & 1 & \\
\hline 詳細 & 67 & 6 & 269 & 322 & 28 \\
\hline
\end{tabular}

資料：「ふくしまの恵み安全対策協議会」ウェブページ （2014 年 8 月）より転記。

\section{5）検査済み表示の添付}

検査を通過した玄米には，全て検査済みラべ ルが添付される，さらに，精米業者は，協議会 に申請を行えば無料で精米ラベル ${ }^{9)}$ が発行され， 精米に添付することが出来る.

ラベルの表記は，厚生労働省の指針 10) と同 じ表現を用いている。ラベルには検査結果を記 載していないものの，QR コードにより協議会 ウェブページを開き，個別識別コードを入力す れば，検査結果を確認することが出来る．表示 内容は, 「検出下限値未満< (測定下限値)」も しくは「(参考値) 検查結果数值」となっている.

\section{4. 米全量全袋検査結果の活用}

\section{1) 基準値超の隔離とその後の出荷管理}

2012 年は, 管理計画区域外でも基準值超が検 出されたため, エリア的な出荷制限が指示され ることとなったが，この制限は短期間（1～5 日） で解除されている. 
このように迅速な制限解除が可能となったの は，管理計画上上モニタリング検査計画上の検 查を,『全量』かつ一部共通仕様で行っているこ と, 市町村の判断により管理計画の対象外区域 でも前年実績に応じて同等の生産管理を行って いたことによる。

出荷制限区域で生産され，管理計画に組み込 むことが出来なければ回収・隔離・廃衰される ことになった玄米が 27 万袋存在している。基 準值超の米を流通・摂取させないだけでなく,

エリア単位の回収・隔離・廃衰を避けられる万 全の体制が構筑されているといえる。

\section{2) 放射性セシウム移行の要因解析}

福島県農業総合センターは, 詳細検査でスク リーニングレベルを超えていることが示された 検体を対象に，協議会・生産者へのヒアリング 等を実施し，検出された要因を分析している。

交差污染（収穫後の立米・紙袋への放射性物質 の付着）が要因である可能性が高い場合を除い て, 土壤成分分析等を行い土壤からの放射性セ シウムの移行の可能性について検証されている.

福島県農業総合センターによると, 詳細検査 にまわる検体は，自給的農家が生産した飯米。

縁故米が多く含まれている。福島県における飯 米・縁故米は $11 \%{ }^{11}$ 程度とされている.『全量』 を母数に，放射性セシウムの稲への移行に関す る研究対象を的確に選定することが可能となっ ている.

\section{3）測定下限值未満での区分出荷}

図1に検査結果の表示方法について整理した。 既に確認したように，検査済みラベルには数值 は表示されないが，協議会ウェブページでは $25 \mathrm{~Bq} / \mathrm{kg}$ きざみで結果が公表され, 個別識別コ ードで検索すれば検查結果数值（参考值）が表 示されるという仕様になっている。

集荷販売現場での米全量全袋検査の結果の取 扱いについて，協議会・農協を対象としたヒア リング調查（2014 年 6〜9 月）を実施したとこ ろ、検查・販売にあたりデータ公開仕様を意識 し『測定下限值未満く $(25 \mathrm{~Bq} / \mathrm{kg})$ 』基準とし た対応が取られていることが分かった。

玄米からの放射性セシウムの検出が確認され
ている JA 新ふくしま(福島市・川俣町), JA みちのく安達（二本松市・本宮市・大玉村）で は， $25 \mathrm{~Bq} / \mathrm{kg}$ 末満の玄米袋を区分出荷できる体 制を整えている。卸売業者には， $25 \mathrm{~Bq} / \mathrm{kg}$ 末満 のみを販売することを伝えて販売交渉を行って いる。ただし，一般消費者に対しては，25Bq/kg 未満のみを単品銘柄で販売していることについ ては,アピールしていない。

一方，玄米からの放射性セシウムの検出が確 認されていない一部の協議会では, ベルトコン ベア式検査器で $25 \mathrm{~Bq} / \mathrm{kg}$ 以上が検出された場合, 詳細検査にまわして正確な測定結果を得るよう 運用している. 須賀川岩瀬協議会（天栄村）に よると，詳細検査にまわす目的は，公開される 検査結果において誤差により『検出下限值未満 $<25 \mathrm{~Bq} / \mathrm{kg}$ 』以上に区分される検体を減らすこ と，25Bq/kg を超えた場合に自主的に要因解析 を行うことである.データ公開仕様を意識し『全 量測定下限值未満く $(25 \mathrm{~Bq} / \mathrm{kg})$ 』を目指した生 産現場での対応であるといえる。

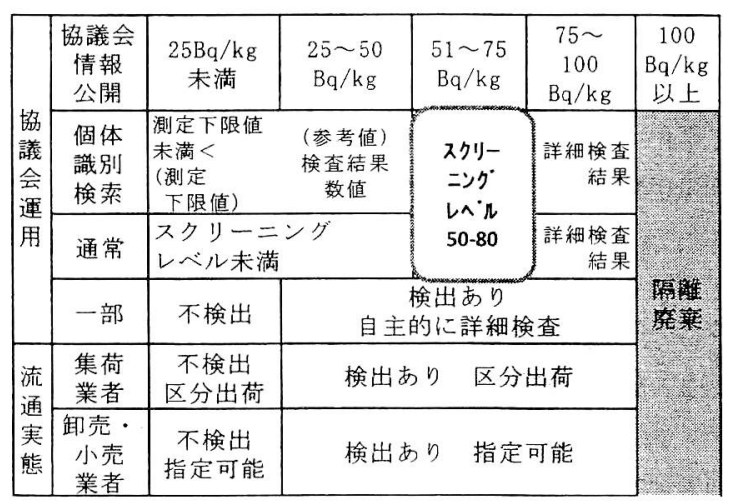

図 1 米全量全袋挨査の結果の表示と区分

資料：福島県水田烟作課「米の全量全袋検査の手引き」 (2012 年 8 月), 協議会・農協調査 (2014 年 6 〜9月）により作成。

\section{5. 考察}

本稿では，米全量全袋検査の運用実態と検査 結果を踏まえ，現行の制度上の問題点を明らか にすること、制度の見直しの方向性を考察する ことが課題であった。

米全量全袋検查に㧍ける問題点は，原子力災 
害対策本部の検査の指針において米全量全袋検 査の位置づけが定められておらず，福島県のみ が自らの判断で米全量全袋検査を計画に組み込 んでいることである.

福島県では，管理計画とモニタリング検査計 画に基づく米全量全袋検査を一部共通仕様とし て行ったことにより，(1)基準值超の米の攝取・ 流通の防止，(2)エリア単位の回収・隔離・廃棄 の回避（2012 年産 7 地区 27 万袋），(3)迅速な 出荷制限解除が実現した。このように，地方自 治体が独自に厳しい管理体制を構築したことで, 原子力災害対策本部の指針レベルの体制では, 基準值超の発見とその後の迅速な対応が困難で あったことが事後的に明らかになったといえる。

このことから，多額の費用を投じる米全量全 袋検查を，地方自治体の判断で実施している現 制度の見直しが必要であると考える．原子力災 害対策特別措置法に基づく現行の法制度の下で の対応であっても，原子力災害対策本部が厚生 労働省・農林水産省・文部科学省と都道府県等 がもつデータを総合的に判断して，米全量全袋 検査の実施エリアを指示する枠組みを構筑する べきである。さらには，放射性物質対策を包括 した新たな法令を整備し，米を含む食品の検査， 放射性物質の污染実態調查，除染・吸収抑制対 策等の手法・範囲を体系的に定める体制へ転換 することが求められているといえる.

米全量全袋検査の枠組みの再構築にあたって は，飯米・縁故米の検査が位置づけを明確にす べきである。モニタリング検査計画によるスク リーニング検査の原則に沿えば，出荷・販売目 的の玄米のみが検查対象となり，飯米・縁故米 は検查対象にならない。福島県では管理計画と 同様に，モニタリング検査計画でも『全量』を 対象としたことで，前述した(1)(2)(3)を可能とし ている。さらに，『全量』を母数に污染された玄 米を見つけ出し，放射性セシウムの稲への移行 に関する研究対象とすることが可能となってい る。国民の健康在守るという観点，米人の放射 性物質の移行の実態を綿密に把握するという観 点から考えて，現状の制度では位置づけられて いない飯米・縁故米の検查体制のあり方を検討
すべきである。

最後に, 米全量全袋検查の運用実態を分析す る中で，生産・流通現場では『測定下限值未満』 を目指した対応が強く意識されており，一部の 集出荷業者では, 『測定卜限值未満 $<25 \mathrm{~Bq} / \mathrm{kg}$ 』 での区分出荷が常態化していることが確認され た 12)。福島県では『モニタリング検査として米 全量全袋検査を実施し, 費用は東京電力に請求, 結果表示は厚生労㗢省指針と同じ表現』という 枠組みの中で検査を実施している。費用の自己 負担を前提にすれば『法令よりも厳しい基準で 流通管理している』とのアピールも可能である が，現行体制の下では，『測定下限值未満』のみ の生産・流通を強調する PR 活動を控えている. 制度上の位置づけにより，消費者へのアピール 内容と『検出下限值未満』での流通実態との間 にギャップが存在していることが附帯的に明ら かになったといえる。

注

1) 関谷 (7) は, 社会心理学による現状認識を踏ま えた風評被害の対策として，(1)事実の理解，(2) 「検査体制」「吸収抑制対策」を伝える，(3)「安 全・安心」を強くアピールしないことが重要で あると論じている。関谷・廣井〔8]の引用は， この枠組みに基づいた指摘である。

2) 日本学術会議 [6]に対し，唐木 [3] は，米全 量全袋検查を実施した 2012 年の福島県産米に ついて,「中通り産と浜通り産のコシヒカリの価 格をほかの産地のものと同じレベルに引き上げ る効果はなかった」ことを根拠に,「米の全量全 袋検査を実施してもその成果が必ずしも明らか ではないとき,“放射性物質の検査態勢の体系化 と組織体制の整備”が風評被害対策にはなり得 ないことは明らかである」と言及している。

3 ) 福島県産米の価格動向については,小池ほか [4] 参照のこと.

4） 2012 年度は, 福島県「出荷制限区域において産 出された平成 24 年産米に関する福島県管理計 画」に基づき，(1)平成 24 年産米の事前出荷制 限区域及び事前出荷制限区域が所在する市町村 から事前出荷制限区域と一体的に管理を行う旨 
の申し出があった区域（10市町村），(2)収穫後 0)娭査結果に基づく平成 24 年産の出荷制限区 域（7市町村）で実施された。

5 ） 2013 年度は,「平成 25 年産米に関する福島県管 理計画」「平成 25 年産米に関する宮城県管理計 画」に基づいて実施された。福島県では(1)作付 制限区域（7 市町村），(2)作付再開準備区域（5 市町村)，(3)全量生産出荷管理区域(12市町村), 宮城県では, 平成 24 年産で $100 \mathrm{~Bq} / \mathrm{kg}$ を超える 放射性セシウムが検出された区域（栗原市旧沢 辺村）が対象となっている。

6 )この事業では, (1)安全管理システム熙急強化対 策として協議会設置・検査機器整備予算を, (2) 安全安心見える化対策として安全管理基本シス テムの構筑・管理運営予算を組んでいる.

7 ）損害賠償請求の支払いには時間がかかるため, 福島県は「米の全量全袋検査推進事業」(2012 年度 60 億円, 2013 年度 50 億円, 2014 年度 66 億円）により，協議会につなぎ資金として無利 子貸付けを行っている。

8) 放射性セシウム濃度の高い米が発生する要因に ついては, 福島県・農林水産省〔2〕が「基準 值超過の発生には, 様々な要因が複合的に関釈 しており，超過視点の要因解析など残された課 題がある」とし,「基準值超過は限定的であるも のの, 継続して調査・要因解明が必要である」 と指摘している。

9 )「安全な福島県のお米/放射性物質検査を実施し た玄米を使用しています/QRコード」と記載さ れている。

10）「食品中の放射性物質の検䍒結果及び検查結果 の)報告について(平成 24 年 3 月 30 日付厚生労 働省医楽食品局食品安全部監視安全課事務連 絡)」.

11）福島県農林水産部農産物流通課調へ, 2008 年産 44 万 $\mathrm{t}$ :対し飯米・縁故米は 4.6 万 $\mathrm{t}$ (推計).

12）関谷 (7) の,「生産者・流通業者・消費者の間 で事実上，結果的に合意した許容量としてこの 検査機器の設定した検出限界では放射性物質は 検出されなかったという意味の「ND（検出限 界值以下)」がデファクトスタンダードとなって きている」との指摘と合致している.
. 引用文献

（1）福島県農林水産部水田畑作課「米の放射性 物質全量全袋検查に関するアンケート調査 結果概要」，2014 年 1 月。

（2）福島県・農林水産省「放射性セシウム濃度 の高い米が発生する要因とその対策につい て〜要因解析調査と試験栽培等の結果の取 りまとめ〜 (概要)」, 2013 年 1 月.

〔3〕唐木英明「福島県産農産物の風評被害に関す る日本学術会議「緊急提言」の疑問点」 『ISOTOPE NEWS』No.718, 日本アイソト 一プ協会, 2014 年 2 月, ppp.38-41.

（4）小池(相原)晴伴 - 伊藤亮司 - 小松知末 - 小山 良太「東日本大震災の前後における米流通の 変化一福島県産米を中心として一」日本農業 市場学会大会個別報告配付資料, 2014 年 7 月.

〔5〕小山良太・小松知末「放射線量分布マッブと 食品検査体制の体系化に関する研究一ベラル 一シ共和国と日本の原子力発電所事故対応の 比較分析一」『2012 年度日本農業経済学会論 文集』2012 年 12 月, pp.215-222.

（6〕日本学術会議東日本大震災復興支援委員会 福島復興支援分科会「原子力災害に伴う食 と農の「風評」問題対策としての検査態勢 の体系化に関する緊急提言」, 2013 年 9 月, pp.1-16.

(7)関谷直也「東京電力福島第一原子力発電所事 故における風評被害の課題」『農村経済研究』 第 32 巻第 1 号, 東北農業経済学会, 2014 年 3 月, pp. $36 \cdot 47$

（8）関谷直也 - 廣井悠「東日本大震災後の価値観 の変化とメディア産業の $\mathrm{BCP}$-震災直後の状 況と消費行動 - 安全観 ·人生観の変化からメ ディア産業の $\mathrm{BCP}$ を考えるー」平成 25 年度 助成事業報告書, 吉田秀雄記念事業財団, 2014 年, pp.63-74.

[9]山川充夫 - 小山良太・石井秀樹「唐木英明氏 「福島県産農産物の風評被害に関する日本学 術会議「緊急提言」の疑問点」への回答」 『ISOTOPE NEWS』No.723, 日本アイソト 一プ協会, 2014 年 7 月, pp.38-43. 
要旨：本稿では, 福島県における米全量全袋検査の運用実態と検査結果を詳細に整理した上で, 制度上の位置づけとその問題点を明らかにした。第一に，福島県が米全量全袋検査を実施してい ることが，放射性物質検查に関する制度の枠組みの中でどのように位置づけられているかを整理 した。第二に，福島県における検査の実施体制と検査結果を詳細にまとめた，第二に，検査結果 の活用実態を確認した。これらを総合的に考察した結果, 制度上の問題点と見直しの方向性は下 記のようであるといえる. 問題点は，原子力災害対策本部のモニタリング検査の指針において米 全量全袋検查の位置づけが定められておらず，福島県のみが自らの判断で検査を計画に組み込ん でいることである. 2012 年度に福島県が実施した米全量全袋検査の結果から, 原子力災害対策本 部の指針レベルの体制では，基準値超の発見と迅速な対応が困難であったことが明らかになった． このことから，現行制度を見直し，原子力災害対策本部が総合的に判断して，検査エリアを指示 する枠組みを構筑するべきであるといえる，また，現状の制度では位置づけられていない飯米・ 縁故米の検查体制のあり方を検討すべきであるといえる.

キーワード：米検査，放射性物質検査，米流通 